\author{
Marcin Łysko \\ University of Bialystok, Poland \\ ORCID: 0000-0002-2789-4679 \\ marcin.lysko@uwb.edu.pl
}

\title{
Operation of Retraining Minor Offences into Misdemeanours in the People's Poland
}

\author{
Operacja przekwalifikowania drobnych występków \\ w wykroczenia w Polsce Ludowej
}

\section{SUMMARY}

In the period of the People's Poland (1944-1989), ruled by the communists, Poland was in the sphere of influence of the Soviet Union. The Act on the Transfer of Certain Minor Offences as Offences to Criminal-Administrative Jurisdiction, passed in 1966, gave the status of a misdemeanour to a large group of existing offences against property and acts detrimental to consumer interests. The purpose of transferring these offences as misdemeanours to the jurisdiction of penal-administrative colleges was to relieve the courts of the burden of dealing with cases of minor offences. The transfer operation was accompanied by the introduction of a number of solutions in the field of criminal law, which created conditions for a more flexible criminal policy in cases of misdemeanours. The Transfer Act was fully incorporated into the Code of Misdemeanours adopted in 1971, the specific part of which includes another group of misdemeanours resulting from the transformation of existing offences. The Transfer Act finally placed the law on misdemeanours in the area of criminal law in its broadest sense, which resulted in a departure from the concept of the misdemeanours law, developed during the Stalinist period, as one of the branches of administrative law.

Keywords: cases of minor offences; misdemeanours law; the Transfer Act; the People's Poland 


\section{ORIGIN OF THE TRANSFER ACT}

One of the most important stages in the process of evolution of the offence law of the People's Poland ${ }^{1}$ was the entry into force of the Act of 17 June 1966 on the Transfer of Certain Minor Offences as Offences to Criminal-Administrative Jurisdiction ${ }^{2}$. The Act definitively determined the further direction of codification work in the area of substantive law of misdemeanours, which after a four-year break was resumed in 1967 due to the publication of a draft criminal code. In accordance with the principle of comprehensiveness of codification works published in 1966, the draft was to serve as a point of reference for other legal acts in the field of broadly understood criminal law, including future codification of the misdemeanours law. It was made pursuant to the Acts passed on 20 May 1971, i.e. Code of Misdemeanours ${ }^{3}$, Code of Conduct in Misdemeanour $\mathrm{Cases}^{4}$ and the Act on the System of Colleges for Misdemeanours Cases ${ }^{5}$.

Until the comprehensive codification came into force, the core of the system of the misdemeanour law was the Act of 15 December 1951 on Criminal-Administrative Jurisdiction ${ }^{6}$, passed at the apogee of Polish Stalinism, which introduced a collegial model of resolving offence cases with the participation of a social factor. The colleges adjudicating at local administrative bodies - presidencies of national councils - functioned initially at all levels of the country's territorial division. The members of the adjudicating colleges representing the social factor were elected by the local authorities - national councils - from among candidates proposed by social and political organizations of the working people and workplaces ${ }^{7}$. In accordance with the principle of collegiality, the misdemeanour cases were identified by three-member formations based on a social factor, while the chairperson of the college was to represent the clerical factor due to sitting on the bureau of the national council $^{8}$. The judicial review of criminal-administrative case-law was replaced by an administrative procedure-based appeal to the college of second instance. The Minister of the Internal Affairs supervised the criminal-administrative case-law,

1 People's Poland is a period in the history of the Polish state between 1944 and 1989. At that time, Poland remained under the influence of the Soviet Union. The country was ruled by the communist party - the Polish United Workers' Party.

2 Journal of Laws 1966, no. 23, item 149, hereinafter: the Transfer Act.

3 Journal of Laws 1971, no. 12, item 114.

4 Journal of Laws 1971, no. 12, item 116.

5 Journal of Laws 1971, no. 12, item 118.

6 Journal of Laws 1951, no. 66, item 454.

7 M. Łysko, Socjalistyczna reforma orzecznictwa karno-administracyjnego Polski Ludowej, [in:] Księga pamiątkowa dla uczczenia pamięci Profesor Krystyny Kamińskiej, ed. A. Gaca, Toruń 2013, pp. 322-323.

${ }^{8}$ K. Siarkiewicz, Ksztattowanie się ustroju kolegiów, „Zagadnienia Wykroczeń” 1977, no. 4-5, p. 36. 
which was expressed, among other things, in the issuing binding guidelines on criminal policy in criminal misdemeanour cases to the formation of the colleges.

In December 1958, the Act on Criminal-Administrative Jurisdiction was subject to a thorough systemic amendment ${ }^{9}$. The amendment departed from the misguided socialist concept of educating offenders in favour of introducing solutions of a typically repressive nature. The colleges gained the right to impose a basic arrest sentence of up to 3 months in cases of misdemeanours that in practice took the form of hooligan acts and misdemeanours that included drunkenness of the perpetrator ${ }^{10}$. As a result of granting the right to apply a penal measure of an isolating nature to colleagues, the institution of referring the case to court, which had been abolished by the reform of December 1951, was partially reinstated. However, the judicial review did not cover the rulings of the colleges providing for the conversion of a fine not paid on time into a substitute custody penalty, although the amended Act on Criminal-Administrative Jurisdiction did not provide for any restrictions on the application of this penalty ${ }^{11}$.

Guided by the assumption that the "repressiveness" of the penal-administrative law system would be tightened, the reform of December 1958 increased the upper limit of the fine by half, which resulted in a significant increase in the material severity of the penalties imposed by the colleges for the most serious misdemeanours. The colleges were deprived of the possibility to discontinue proceedings in the case of minor social harm caused by the deed, which meant an obligation to punish the perpetrators of even the most minor misdemeanours each time. The only relic of the educational character of the penal-administrative jurisdiction remained the penalty of reprimand, introduced instead of a warning, although it could not be imposed on the perpetrators of misdemeanours threatened with imprisonment. The changes made as a result of the reform of December 1958 in the scope of the system and organization of colleges were beneficial, especially the departure from the principle of the obligatory establishment of colleges at the level lower than the district level. The college at the presidium of the poviat national council, introducing at the same time the requirement for the president of that college and his deputies to have legal education, became the basic link in the organizational structure ${ }^{12}$.

9 Act of 2 December 1958 on Amending the Act of 15 December 1951 on Criminal-Administrative Jurisdiction (Journal of Laws 1958, no. 77, item 396).

10 These were the following misdemeanours: disturbing the public peace, violating the law and order regulations on behaviour in public places, disturbing night-time rest, committing acts of indecency and using indecent words. Arrest could also be ordered for disturbing public order or causing public umbrage in a state of intoxication. See J. Bafia, O zaostrzeniu i przyśpieszeniu odpowiedzialności karnej za chuligaństwo, Warszawa 1959, p. 110.

${ }^{11}$ A. Gubiński, Ewolucja stosowanych przez kolegia środków karnych i zasad wymiaru kary, „Zagadnienia Wykroczeń” 1977, no. 6, pp. 29-30.

${ }_{12}$ M. Łysko, Reforma prawa karno-administracyjnego Polski Ludowej z 1958 r., „Z Dziejów Prawa" 2014, vol. 7, pp. 238-239. 
From the point of view of the authorities, the reform of December 1958 was undoubtedly a success, as granting the colleges the possibility of severe penalties contributed to reducing the social scourge of hooliganism and to a general improvement in the security in the country. On the other hand, changes of an organizational and systemic nature resulted in a noticeable improvement in the level of functioning of penal-administrative jurisprudence, including solving the problem of excessive influence of penal motions drawn up by law enforcement agencies. However, the overly formalistic nature of the amended provisions of the Act on Criminal-Administrative Jurisdiction, which impose the obligation to punish every offender, forced the colleges to conduct proceedings even in cases with a low weight. Considering such cases constituted a serious burden for the colleges, which, according to the guidelines of the Ministry of the Internal Affairs, were to focus primarily on punishing the perpetrators of socially dangerous alcohol and hooligan misconduct and misdemeanours against road safety ${ }^{13}$. In addition to the increasing need to mitigate the excessive repressive nature of the Polish system of the misdemeanours law, its further development was significantly influenced by the concept of the so-called stratification of crime adopted by the Gomułka authorities in March 1961. The concept, which determined the legislative policy in the field of broadly understood criminal law, assumed a different approach to minor, accidental violations of the legal order and assaults causing significant damage to the social interest ${ }^{14}$.

The concept of stratifications of crime was reflected in a draft criminal code published in 1966. The project assumed partial decriminalisation of petty economic crimes and offences against public order, which were to be transformed into the misdemeanours under the jurisdiction of the colleges ${ }^{15}$. The acceptance of the socio-political assumptions of the project by official factors gave the green light to the codification work in the field of misdemeanour law. The starting point for the codification work carried out in 1967-1971 was the Transfer Act, on the basis of which numerous acts of a general criminal nature were shifted from the area of criminal law to the law of misdemeanour. This operation was carried out by "halving" the actual state of some minor offences, which partly became misdemeanours and partly retained the nature of the offences. Among the arguments justifying the adoption of such a solution, the most important was the consideration of speeding up and reducing the costs of proceedings. The adoption of the Act was supposed to contribute to relieve the courts from the excess of minor cases, and at the same time to facilitate the prosecution and holding responsible the perpetrators of acts

13 Wytyczne Ministra Spraw Wewnętrznych w zakresie orzecznictwa karno-administracyjnego na rok 1960, „Poradnik dla Kolegiów Orzekających” 1960, no. 2, p. 2.

14 S. Walczak, Niektóre problemy kodyfikacji prawa karnego, „Państwo i Prawo” 1968, no. 4-5, p. 594.

${ }^{15}$ Projekt kodeksu karnego. Część szczególna, Warszawa 1966, p. 46. 
of lesser social harm ${ }^{16}$. The subjection of minor offences as misdemeanours to criminal-administrative jurisdiction was associated with hopes for a change in the policy of punishing the perpetrators of this type of acts, where economic repression expressed in fines was to play a decisive role ${ }^{17}$.

\section{MISDEMEANOURS RESULTING FROM THE TRANSFORMATION OF EXISTING OFFENCES}

As part of the transfer operation, nine offences have been submitted to the jurisdiction of the colleges, treated in the practice of the justice system as acts of minor or even insignificant social danger. Among the so-called transferred misdemeanours, the most important were the acts against property, which were most frequently encountered by the justice administration. Convictions for crimes against social and individual property constituted about $35 \%$ of all sentences passed, but the number of actually committed crimes was much higher ${ }^{18}$. The second category of cases was minor speculative offences, and the list of transferred misdemeanours was supplemented by carrying out gainful activity without the required permit ${ }^{19}$.

In the group of misdemeanours against property, the leading position was taken by petty thefts and misappropriations of property with a value not exceeding PLN 300. Theft was understood as the taking of another person's movable property for the purpose of misappropriation. On the other hand, misappropriation consisted in the arbitrary disposal of property legally owned by the perpetrator, e.g. entrusted for storage or lent. The Transfer Act did not differentiate the amount of the criminal penalty depending on the type of property subject to the misdemeanour, although the Constitution of the People's Republic of Poland of 22 July $1952^{20}$ provided for special protection of social property. Social property, which was the basis of the social and economic system, was divided into state and cooperative property and was subject to criminal law protection in a number of laws and decrees issued in

16 This was to be a consequence of relieving the Civic Militia (Police in People's Poland) bodies from conducting preparatory proceedings in a significant part of the cases of previous offences, which have been transformed into misdemeanours. The information on the offences transferred from the courts to the jurisprudence of the colleges by the Act of 17 June 1966, Archive of New Records in Warsaw, resource Ministry of Justice, sign. 5/2, p. 46.

${ }_{17}$ Ogólne założenia ustawy, „Zagadnienia Karno-Administracyjne” 1966, no. 5, pp. 1-3.

18 This was owing to the fact that a number of cases of petty thefts did not meet with a response from law enforcement authorities as the victims did not report the crime. Moreover, prosecutor's offices and courts often discontinued instituted proceedings, attributing to the acts covered by them negligible social harm. See L. Hochberg, Rodzaje wykroczeń, „Zagadnienia Karno-Administracyjne” 1966, no. 5, p. 34 .

${ }^{19}$ Ogólne założenia ..., pp. 5-6.

${ }^{20}$ Journal of Laws 1952, no. 33, item 232. 
People's Poland. Unlike social property, the Constitution of the People's Republic of Poland only tolerated private ownership of means of production and personal property of individual citizens, providing for the protection of these forms of property in ordinary legislation ${ }^{21}$. On the basis of the Transfer Act, the constitutional principle of special protection of social property was expressed only in a solution providing for an obligatory ruling by the college on the obligation to return the equivalent of stolen or misappropriated social property ${ }^{22}$.

By introducing the criterion of the amount of PLN 300 in order to delimit the offences from misdemeanours, the authors of the act referred to the concept binding on the basis of legal acts issued in the People's Poland to ensure special protection of social property ${ }^{23}$. The theft or misappropriation of wood from the forest was an exception, where the amount determining the qualification of an act as an offence was set at only PLN 150, as the specific object of the act and the way the perpetrator acted. In line with the assumption of special protection of forest resources, it was stipulated that, in addition to the basic penalty, the amount of double value of the stolen or misappropriated wood was mandatory ${ }^{24}$.

In the light of the provisions of the Transfer Act, not every case of theft or misappropriation of an object worth up to PLN 300 was qualified as a misdemeanour, as under certain circumstances such an act constituted an offence. These circumstances concerned the perpetrator ${ }^{25}$, the manner of action ${ }^{26}$ and the object of the act ${ }^{27}$. The

${ }^{21}$ A. Lityński, Historia prawa Polski Ludowej, Warszawa 2006, pp. 218-219.

22 J. Lewiński, Wybrane zagadnienia z ustawy z dnia 17 czerwca 1966 r. o przekazaniu niektórych drobnych przestępstw jako wykroczeń do orzecznictwa karno-administracyjnego, „Nowe Prawo” 1967, no. 2, p. 230.

${ }^{23}$ This is the first time that the amount of PLN 300 was included in the Decree of 4 March 1953 on the Protection of Social Property Against Minor Attacks (Journal of Laws 1953, no. 17, item 69). Then it was transferred to the Act of 18 June 1959 on Criminal Liability for Crimes Against Social Property (Journal of Laws 1959, no. 36, item 228). It constituted a criterion for separating an act where due to the low value of seized property an extraordinary leniency or a milder punishment in case of recidivism could be applied. See J. Skupiński, Przekazanie niektórych drobnych przestępstw do orzecznictwa karno-administracyjnego, „Państwo i Prawo” 1967, no. 1, p. 112.

${ }^{24}$ L. Jastrzębski, Kradzież drewna z lasu, „Zagadnienia Karno-Administracyjne” 1966, no. 5, pp. 98-99.

${ }^{25}$ According to Article $16 \S 4$ para. 1 of the Transfer Act, the offender was treated as a criminal when he managed stolen or misappropriated social property or was responsible for the social property entrusted to him by virtue of his function.

${ }^{26}$ According to Article $16 \S 2-4$ of the Transfer Act, criminal liability was provided for by the Transfer Act in case of: burglary; use of violence or threat to take or retain property; misappropriation or theft of social property within an organized criminal group.

27 Pursuant to the provisions of Article $16 \S 1$ para. 2 of the Transfer Act, the jurisdiction of the college was also excluded in a situation where weapons or ammunition were stolen or misappropriated. The exclusion was justified by the high social risk of the very fact of illegal possession of weapons or ammunition. 
occurrence of at least one of these circumstances resulted in classifying the act as a crime subject to the jurisdiction of criminal courts ${ }^{28}$.

The group of the so-called transferred misdemeanours was supplemented by receiving and handling of stolen property and an act consisting in damaging an item or making it unusable. The misdemeanour of receiving and handling stolen goods consisted in acquiring or accepting for other purposes property from theft or misappropriation, as well as providing assistance in disposing of or hiding such property. The key to considering an act as a misdemeanour was the fact that the receiver purchased or accepted property with a value not exceeding PLN 300, and in the case of wood with a value up to PLN 150. In turn, in the case of a misdemeanour of damaging the property or making it unusable, the amount of the damage was decisive, which should not have exceeded PLN 300. The reason why such an act could not be considered a misdemeanour was that it was committed with the use of fire, explosives or flammable materials. Another exclusion was related to cases where the act of damaging the property or making it unusable was of a hooligan nature ${ }^{29}$.

The second group of transferred misdemeanours were acts taken over from the so-called Anti-profiteering Act passed in $1957^{30}$. Their submission to the jurisprudence of the colleges was based on the criterion of the value of the object of the act in the amount not exceeding PLN 300. In the first place, it was a misdemeanour to speculate on goods purchased in the state retail trade network, i.e. its further resale for profit ${ }^{31}$. The Transfer Act also penalised the profiteering sale of admission tickets to shows or events, consisting in offering or selling tickets at a price higher than the nominal one ${ }^{32}$. Another misdemeanour taken over from the Anti-profiteering Act was the charging of a fee higher by no more than PLN 300 for the provision of services by persons professionally engaged in providing them ${ }^{33}$. An act of removing a permanent mark of price, quality or origin of goods was also sanctioned a misdemeanour. On the other hand, in the case of cheating buyers of goods in retail outlets, the misdemeanour was an act which caused the buyer damage not exceeding PLN $50^{34}$. The same article of the Act provides for the liability of

${ }^{28}$ Ogólne założenia..., pp. 3-4.

29 A. Gubiński, M. Siewierski, Ustawa o przekazaniu niektórych drobnych przestęstw jako wykroczeń do orzecznictwa karno-administracyjnego. Komentarz, Warszawa 1967, pp. 46-49.

30 Act of 13 July 1957 on Combating Profiteering and Protecting the Interests of Buyers and Agricultural Producers in Trade (Journal of Laws 1957, no. 39, item 171).

${ }^{31}$ L. Hochberg, Doniosłe zmiany w orzecznictwie karno-administracyjnym, „Służba MO” 1967, no. 1, p. 22.

32 A. Gubiński, M. Siewierski, op. cit., p. 58.

33 J. Chabros, Żadanie i pobieranie za ustugi cen wyższych od obowiazujacych, „Zagadnienia Karno-Administracyjne" 1966, no. 5, pp. 101-103.

${ }^{34}$ L. Hochberg, Donioste zmiany..., p. 21. 
a seller who used an unreliable measuring tool to deceive a buyer for an amount not exceeding PLN $50^{35}$.

A separate type of offence regulated in the Transfer Act was to conduct manufacturing, processing, trade or service activities without the required permit. Regarding the fact that determining the precise amount of damage caused was impossible, the criterion separating the offence from the misdemeanour was an unclear premise for a lesser significance of the act $^{36}$.

As a consequence of transforming existing offences into misdemeanours, the number of penalties for minor criminal offences was reduced. The Transfer Act operated with an alternative sanction, which consisted of custody penalties of up to 3 months and fines of up to PLN 4,500. The establishment of the maximum ceiling for these penalties provided for in the Act on Criminal-Administrative Jurisdiction was justified by the weight of the transferred misdemeanours, which were to constitute the most serious category of cases subject to the jurisdiction of the colleges. Only in the case of a misdemeanour of unintentional receiving and handling of goods the upper limit of the fine was lowered to PLN 3,000 ${ }^{37}$.

In the partial decriminalisation of existing offences, the possibility of excessive leniency of the repressive policy in cases of minor criminal acts was taken into account ${ }^{38}$. In order to prevent the colleges from treating relatively leniently, the perpetrators of acts of considerable social danger, exemptions from the scope of the Transfer Act were provided for. These took the form of premises, the occurrence of which resulted in classifying the acts provided for in the Act as offences. These reasons were recidivism and the hooligan nature of the perpetrator's actions. Recidivism consisted in committing one of the transferred misdemeanours within the period of 5 years following a final court verdict or within the period of 2 years following a final college verdict ${ }^{39}$. Submission of transferred misdemeanour cases to the jurisdiction of criminal courts in certain cases helped to strengthen the links between the criminal-administrative case-law and the judiciary, which were broken as a result of the abolition of judicial review of the case-law on misdemeanours by the Act on Criminal-Administrative Jurisdiction.

35 J. Szubert, Odpowiedzialność karno-administracyjna $w$ prawie o miarach i narzędziach pomiarowych, „Zagadnienia Karno-Administracyjne” 1966, no. 6, pp. 9-10.

${ }^{36}$ L. Hochberg, Rodzaje..., p. 44.

37 I. Śmietanka, Zasady odpowiedzialności i karania, „Zagadnienia Karno-Administracyjne” 1966, no. 5, p. 21.

${ }^{38}$ Note of the Ministry of Justice of 24 February 1966 on the draft law on transfer against the background of the directives of the Secretariat of the Central Committee of the Polish United Worker's Party on penal policy, Archives of Modern Records in Warsaw, resource Ministry of Justice, sign. 1981, p. 138.

${ }^{39}$ F. Józwiak, Zadania Milicji Obywatelskiej, „Zagadnienia Karno-Administracyjne” 1966, no. 5 , p. 80 . 


\section{NEW SOLUTIONS INTRODUCED INTO THE CRIMINAL-ADMINISTRATIVE LAW SYSTEM}

In addition to solutions for offenders resulting from the partial decriminalisation of existing offences, the Transfer Act contained new institutions unknown to the law to date. These were taken into account in the novelisation of the Act on Criminal-Administrative Jurisdiction, which applied to all misdemeanours considered under the procedure regulated by this $\mathrm{Act}^{40}$. Flexible penal policy towards offenders was achieved by introducing the institutions provided for in the draft criminal code of 1966, which were to abolish the imposition of a sentence and suspend the execution of the basic custody sentence. The dispensation from serving a sentence took place in a situation where, in the opinion of the college, serving sentences even at the lowest level would be pointless due to the nature and circumstances of the act or the personality of the offender ${ }^{41}$. When the college did not impose a penalty, it had a choice between a warning and another social measure ${ }^{42}$. It could also oblige the offender to restore the violated legal order or to compensate for the damage caused ${ }^{43}$.

Another of the new institutions was a conditional suspension of the execution of the custody sentence for a trial period of 6 months to one year. It could be applied by the college in the case of an acknowledging that despite failure to comply with the sentence imposed, the offender will not commit a new misdemeanour of the same type during the trial period. The grounds for conditional suspension of custody were divided into two groups. The first group consisted of the offender's personal qualities and conditions. The perpetrator's qualities were understood as personality traits, degree of intelligence or mental development independent of him. The personal conditions concerned the environment in which the perpetrator lived, his work and family relations. Another group of premises was formed by the circumstances accompanying the perpetrator's misconduct and the perpetrator's behaviour afterwards. The application of the conditional custody warrant by the college did not require the common occurrence of all the conditions listed by the legislator. Making a decision in this case, the amended Act on Criminal-Administrative Jurisdiction left the college

40 M. Siewierski, Przepisy procesowe, „Zagadnienia Karno-Administracyjne” 1966, no. 5, p. 46.

${ }^{41}$ A. Postan, Duże zadania matej sprawiedliwości, „Gazeta Sądowa i Penitencjarna” 1966, no. 9 , p. 1.

${ }^{42}$ Although the Transfer Act did not contain a definition of the concept of social impact measure, the doctrine created this definition based on the statutory context. Measures of social impact were to be those that were not regulated by law and whose enforcement was not secured by a state coercive sanction. The perpetrator subordinated to them on a voluntary basis. See J. Skupiński, Model polskiego prawa o wykroczeniach, Wrocław 1974, pp. 154-155.

43 J. Bafia, Ustawa o przekazaniu niektórych drobnych przestęstw jako wykroczeń do orzecznictwa karno-administracyjnego, „Nowe Prawo” 1966, no. 11, p. 1347-1348. 
at its discretion, which could impose an unconditional penalty of basic custody ${ }^{44}$. In the case where the object of the misdemeanour was social property, a conditional suspension of the custodial sentence was permissible on condition that the perpetrator compensated for the damage caused to the property ${ }^{45}$.

The transfer of the institution of conditional suspension of custody was intended to further restrict the use of isolationist penalties by colleges. The previous practice of the jurisprudence of the colleges was to demonstrate the abuse by the colleges of the powers granted to them under the novelisation of the Act on Criminal-Administrative Jurisdiction of December 1958, in particular the substitute custody applied to those sentenced to fines ${ }^{46}$. The scale of the application of this penalty significantly exceeded the expectations that the legislator had to impose with the introduction of the restoration of substitute custody ${ }^{47}$. Hence, from 1961 onwards, guidelines issued by the Minister of the Interior emphasized that "the basic means of repression in criminal-administrative proceedings should be a fine without replacing it with the penalty of substitute custody"48. The consistent attitude of the supervisory authorities began to bring results in the form of a gradual reduction in the number of alternative custody sentences ${ }^{49}$. Between 1960 and 1967 there was a significant decrease in the scope of this penalty from $77 \%$ to $17 \%$ of the total fine ${ }^{50}$.

Although the revised Act on Criminal-Administrative Jurisdiction left the application of the basic custody sentence to the college's discretion, this decision was subject to at least one of three conditions. These were the seriousness of the act committed, a high degree of demoralisation of the perpetrator or his manner of

${ }^{44}$ M. Szewczyk, Warunkowe zawieszenia wykonania kary aresztu orzeczonej przez kolegium za wykroczenie, „Państwo i Prawo” 1967, no. 5, pp. 613-614.

${ }^{45}$ I. Śmietanka, Zasady odpowiedzialności..., pp. 30-31.

46 This was particularly evident in the first years of the amended version of the Misdemeanour Code in December 1958, when substitute custody was imposed on $77 \%$ of those fined in 1960 and $55 \%$ of those fined in 1961. See A. Gubiński, Areszt zasadniczy i zasteppczy, „Zagadnienia Karno-Administracyjne" 1963, no. 6, p. 56.

47 The Social and Administrative Department, acting on behalf of the Minister of the Internal Affairs, criticised the practice of abuse of alternative custody, which applied to $78 \%$ of the fines issued by the colleges between 1959 and 1960. It was stressed that "thus, the provision being an auxiliary measure in the work of the colleges, became a rule contrary to the intentions of the legislator and the principles of proper criminal policy” (Nasze aktualne zadania, „Zagadnienia Karno-Administracyjne” 1961, no. 1, p. 2).

${ }^{48}$ This was the first time that this took place in the guidelines of the Minister of the Internal Affairs of 17 June 1961. See Na antywykroczeniowym ,froncie”, „Zagadnienia Karno-Administracyjne" 1961 , no. 5 , p. 10.

49 Substitute custody was imposed on $34.4 \%$ of those fined in $1963,22.8 \%$ in 1964 and $17.9 \%$ in 1965. See Orzecznictwo karno-administracyjne w latach 1963-1965, „Zagadnienia Karno-Administracyjne" 1966 , no. 3-4, p. 8.

${ }^{50}$ Information on the course of the criminal-administrative case law in 1967, Archive of Modern Records in Warsaw, resource Ministry of Justice, sign. 1/377, p. 38. 
acting deserving special condemnation. The limitation of the use of isolating penalties was served by the introduction of the principle of priority for the imposition of a fine, if that fine was an alternative to imprisonment in the sanction of the provision infringed. The Transfer Act also gave an exceptional character to substitute custody, which was manifested by introducing into the Act on Criminal-Administrative Jurisdiction new criteria for converting a fine imposed by the college into substitute custody $^{51}$. This was possible only if it was established, on the basis of an analysis of the overall circumstances of the offender, in particular his material conditions, that the execution of the fine would not be effective ${ }^{52}$.

The novelised Act on Criminal-Administrative Jurisdiction created the basis for a more flexible treatment of minor offenders where their act constituted a breach of their employment obligations. Instead of applying penal measures, there was a possibility to refer the case to the manager of the company where the perpetrator was employed. When referring a case, the president of the college requested to apply the disciplinary measures provided for in the Staff Regulations ${ }^{53}$ or other educational impact measures ${ }^{54}$ used in that company ${ }^{55}$.

\section{MISDEMEANOURS “TRANSFERRED” IN THE 1971 CODE OF MISDEMEANOURS}

The positive assessment of the first years of practical application of the solutions of the Transfer $\mathrm{Act}^{56}$ resulted not only in the full inclusion of its solutions in the Misdemeanour Code, but also in the subjection of another group of minor crimes that have so far constituted offences to the jurisdiction of the colleges. The creators of the specific part of the Misdemeanour Code based their work on the assumption of stratification of socially dangerous acts, which was expressed in the Criminal

${ }^{51}$ A. Postan, op. cit., p. 1.

52 J. Jasiński, Prawo bliżej odbiorcy, „Gazeta Sądowa i Penitencjarna” 1966, no. 20, p. 7.

${ }^{53}$ Disciplinary measures were: a warning, a monition, imposition of a fine, transfer to a lower grade job, dismissal with conditions of notice, dismissal without notice due to the employee's fault. See A. Mirończuk, Oddziaływanie wychowawcze zakładów pracy, „Zagadnienia Karno-Administracyjne" 1966 , no. 5 , p. 90.

${ }^{54}$ Measures of educational influence could take the form of both purely educational as well as repressive, although from the point of view of criminal law they were not punitive. Unlike the social impact measures, the educational measures were expressly provided for by law and their execution was secured by state coercion. See J. Skupiński, Model polskiego prawa..., pp. 154-155.

55 A. Mirończuk, op. cit., p. 91.

${ }^{56}$ In mid-1969, when evaluating the practice of applying the Transfer Act, the Social and Administrative Department of the Ministry of the Internal Affairs expressed the opinion that "The fundamental objective of the Act of Transfer has in principle been achieved" (Information on the transferred offences..., p. 46). 
Code $^{57}$ of the People's Poland of 1969. It gave the status of criminal offences to serious acts, while a number of petty offences were omitted in its specific part. In assessing the continuation of the increased penalisation of such offences for raison d'être, the authors of the Criminal Code advocated their transformation into misdemeanours ${ }^{58}$. In accordance with the principle of harmonising codification works in the area of broadly understood criminal law, the Misdemeanour Code transferred to the jurisdiction of the colleges another group of offences characterised by a low degree of social danger. The rank of the misdemeanour has gained by:

- not leaving the public gathering despite being summoned by a competent authority,

- begging in a public place by a person who has the means of subsistence or is capable of working,

- destroying, damaging or removing signs affixed by a state authority to identify an object,

- driving a motor vehicle while under the influence of alcohol,

- scamming the ride, food, admission to an event, the operation of a machine or other paid service,

- the removal, destruction or damage of items of immaterial value,

- hiding goods from the buyer in a retail company,

- refusal by a professional to provide a service,

- animal abuse ${ }^{59}$.

On the basis of the codification of substantive law of misdemeanours, the acts of receiving and handling, which so far was partly the competence of courts and partly of colleges, gained the uniform nature of the misdemeanours. This was done by resigning from the criterion of the value of the object of the misdemeanour, the exceeding of which, on the grounds of the Transfer Act, resulted in the qualification of a given factual state as an offence. The Code of Misdemeanours transferred the following acts to the exclusive jurisdiction of the colleges:

- conducting manufacturing, processing, trade or service activities without the required permit,

- speculating on tickets to artistic, entertainment and sports events,

- removal of signs from goods or the sale of goods with removed signs,

- demanding and charging for the provision of services a payment higher than that applicable to professionals ${ }^{60}$.

57 Act of 19 April 1969 - Criminal Code (Journal of Laws 1969, no. 13, item 96).

58 J. Bafia, Wzbogacenie środków zwalczania drobnej przestępczości, „Państwo i Prawo” 1968, no. 4-5, pp. 634-635.

${ }^{59}$ I. Śmietanka, Z sądu do kolegium, „Gazeta Sądowa i Penitencjarna” 1970, no. 16, p. 6.

${ }^{60}$ Ibidem. 
Only in the case of acts against property, the existing division into offences and misdemeanours was maintained, increasing the amount separating the two types of punishable acts from PLN 300 to 500.

Political considerations were at the root of a further operation to reclassify the offences into misdemeanours ${ }^{61}$ in 1986, which was in violation of the guarantee function of criminal law. Article 52a, added to the Misdemeanour Code in order to repress the political opposition, made such states of affairs as the preparation and distribution of information materials within the so-called second circulation ${ }^{62}$, or taking action to cause social unrest or riots ${ }^{63}$ subject to colleges jurisdiction. The transfer of these acts from the courts to the jurisdiction of colleges, which were fully disposable to the Ministry of Internal Affairs, was accompanied by the adoption of a broad interpretation of the provisions on the penalty of forfeiture of things for such acts. It allowed for the forfeiture of cars or video equipment ${ }^{64}$, especially if they were used or intended for the purpose of illegal creation and distribution of information materials in the so-called second circulation. This type of practice led to a distortion of the essence of the penalty of forfeiture of property on the grounds of the law of misconduct. Due to the fact that the forfeiture of things of value several times higher than the maximum fine the penalty of forfeiture actually took the form of confiscation of property. The judgements issued after 1986 on the forfeiture of costly items were commonly felt to be an expression of the additional penalty used as an instrument of " $a d$ hoc, spectacular and short-lived political games" No wonder that the aforementioned Article 52a of the Misdemeanour Code was

${ }^{61}$ Pursuant to the Act of 24 October 1986 on Amending Certain Provisions of the Law on Misdemeanours (Journal of Laws 1986, no. 39, item 193).

${ }^{62}$ Point 1 of Article 52a of the Misdemeanour Code provided for the liability of an offender who "without the required authorisation draws up, issues, transports, transfers or distributes works and other information expressed by means of printing or other forms of recording and transmitting them".

${ }^{63}$ In addition, the following offences have gained the rank of offences threatened with penalties of detention, restriction of liberty or fines up to the upper limit of these penalties specified in the Code of Misdemeanours: public provocation to commit a crime or its praise; public incitement to disobedience or counteracting a law or legal regulation of a state body; participation in an illegal relationship, if the scope of the act or its consequences were not significant.

${ }^{64}$ During the first six months of the application of Article 52a of the Misdemeanour Code, the colleges declared nine cars belonging to members of the political opposition to be forfeited, although as a rule these cars were not used directly to commit an offence consisting in the distribution of materials from the so-called second circulation. See Kolegia ds. wykroczeń w PRL (rozwiazania ustawowe i praktyka), Warszawa-Kraków 1987, pp. 17-18 (this brochure was prepared and published through the efforts of the Commission for the Intervention and Rule of Law of the NSZZ "Solidarność" and the Małopolska Committee for the Fight for the Rule of Law).

65 J. Szumski, Główne kierunki polityki karnej realizowane przez kolegia do spraw wykroczeń w latach 1972-1989, „Archiwum Kryminologii” 1993, vol. 19, p. 118. 
repealed on the wave of social and political changes in 1989 just before the first partially free elections in post-war Poland ${ }^{66}$.

\section{CONCLUSION}

The Transfer Act had a significant impact on the process of evolution of Polish criminal law in the $20^{\text {th }}$ century, as it definitively confirmed its affiliation to the area of broadly defined criminal law. The assumption of further codification of substantive misdemeanour law based on the assumption of strict harmonisation of misdemeanour law with criminal law, which accompanied the enactment of the act, meant the collapse of the concept of misdemeanour law as a branch of administrative law, quite strongly represented at the beginning of the 1960s. The view that the concept of misdemeanour law had a similar function to that of criminal law was widely accepted, but that the subject of its interest were acts of a slightly lower social harm than crimes ${ }^{67}$.

The tendency expressed in the Transfer Act to "criminalise" the law of misdemeanours was reflected in the process of gradual introduction of criminal law elements. They displaced solutions created for misdemeanours as acts detrimental to public peace and order and disrupting the organizing activities of the administration $^{68}$. The underlying idea of "halving" criminal acts into crimes and misdemeanours depending on the value of the object or the amount of damage, which was the basis of the transfer operation, led to a further blurring of the differences between the two categories of criminal acts. The generic identity of the transferred offences and misdemeanours entailed the need to enrich the substantive law regulations applicable to the Act on Criminal-Administrative Jurisdiction with substantive and procedural provisions typical for criminal law. The reiterated institutions of the general part of the criminal law applied not only to transferred misdemeanours, as some of them concerned the whole area of substantive misdemeanour law ${ }^{69}$.

The Transfer Act determined the shape of the solutions adopted in the second phase, which was the final result, of the codification works of the Misdemeanour $\mathrm{Act}^{70}$. The 1971 codification not only maintained the legal status created by the

${ }^{66}$ Under the Act of 29 May 1989 on Amending Certain Provisions of Criminal Law, the Law on Misdemeanours and Other Acts (Journal of Laws 1989, no. 34, item 180).

${ }^{67}$ H. Rot, Problemy kodyfikacji prawa w PRL, Wrocław 1978, pp. 108-109.

${ }_{68}$ M. Olszewski, Stopień społecznego niebezpieczeństwa jako podstawa rozgraniczenia przestępstw $i$ wykroczeń, „Państwo i Prawo” 1988, no. 4, p. 58.

${ }_{69}$ M. Szewczyk, Problematyka nieletnich $w$ ustawie o przekazaniu niektórych drobnych przestępstw jako wykroczeń do orzecznictwa karno-administracyjnego, „Palestra” 1968, no. 9, pp. 39-40.

${ }^{70}$ Z. Kocel-Krekora, Kierunki rozwoju polskiego prawa wykroczeń, „Zagadnienia Wykroczen”” 1987, no. 3, p. 11. 
Act, but went much further, taking over another serious group of offences to the group of misdemeanours. The result of this process was a fundamental change in the face of the Polish material law of misdemeanours, which, in addition to traditional misdemeanours of an orderly nature, also included criminal acts. The acts resulting from the transformation of previous offences were distinguished by a relatively high degree of social danger for the misdemeanours ${ }^{71}$. A consequence of the transfer operation was the perception of misdemeanours and crimes as the same category of punishable acts, which differed only in the degree of social danger of the act ${ }^{72}$.

The further tightening of ties between the law of misdemeanours and criminal law was the result of the political reform of $1990^{73}$, which included the whole jurisprudence of the colleges in the scope of judicial control. The culmination of that process took place in 2001 when cases of misdemeanours were given under the exclusive jurisdiction of courts $^{74}$. The abolition of the colleges for misdemeanours ${ }^{75}$ meant the end of dualism in the area of adjudicating bodies, as a result of which one of the key premises underlying the transfer operation carried out in 1966 in the form of relieving the courts of the burden of examining cases of minor criminal offences dropped out. The procedure of considering cases of misdemeanours by courts was shaped in the same way as the criminal trial ${ }^{76}$, which is proved by numerous references to the provisions of the Code of Misdemeanour Cases Procedure of $2001^{77}$. In this situation, it should be questioned whether the introduced law on transferring the division of acts against property into offences and misdemeanours by means of a quota criterion is still valid. Particularly in the case of theft, setting the amount separating an offence from a misdemeanour at PLN 500 unnecessarily burdens law enforcement authorities with the obligation to precisely determine the value of stolen property, as well as results in the application of different procedures for the courts to handle the same type of cases. As an example for the legislator, the status of an offence of drunken driving should be given to an existing misde-

${ }^{71}$ J. Skupiński, Kierunki doskonalenia polskiego prawa wykroczeń, „Studia Prawnicze” 1981, no. 4 , p. 5 .

72 W.F. Dąbrowski, Nowe aspekty orzecznictwa karno-administracyjnego, „Ruch Prawniczy, Ekonomiczny i Socjologiczny" 1967, no. 1, p. 94.

${ }^{73}$ Under the Act of 8 June 1990 on Amending the Acts: Code of Criminal Procedure, Code of Conduct in Misdemeanour Cases, Law on the System of Colleges for Misdemeanours Cases and Labour Code (Journal of Laws 1990, no. 43, item 251).

74 J. Warylewski, Prawo karne. Część ogólna, Warszawa 2015, p. 33.

75 In connection with the adoption of the principle of the administration of justice solely by the courts, the Constitution of the Republic of Poland adopted on April 2, 1997 (Journal of Laws 1997, no. 78, item 483 as amended) provided for the liquidation of colleges within 4 years of its entry into force. See T. Grzegorczyk, Kodeks postępowania w sprawach o wykroczenia, Warszawa 2012, p. 16.

${ }^{76}$ Act of 24 August 2001 - Code of Conduct in Misdemeanour Cases (Journal of Laws 2001, no. 106 , item 1148).

77 Act of 6 June 1997 - Code of Criminal Procedure (Journal of Laws 1997, no. 89, item 555). 
meanour in connection with the entry into force of the Criminal Code of $1997^{78}$. As a result of the resignation from the concept of "halved" actions, all cases of driving a motor vehicle by the perpetrators who are under the influence of alcohol are now considered by the courts in the course of criminal proceedings ${ }^{79}$. A similar solution should be applied to theft and other acts against property, which are artificially separated into offences and misdemeanours by means of a quota criterion and are not justified under the current legal situation.

\section{REFERENCES}

\section{Sources}

Archive of Modern Records in Warsaw, resource Ministry of Justice, signatures: 5/2; 1981; 1/377.

\section{Literature}

Bafia J., O zaostrzeniu i przyśpieszeniu odpowiedzialności karnej za chuligaństwo, Warszawa 1959. Bafia J., Ustawa o przekazaniu niektórych drobnych przestęstw jako wykroczeń do orzecznictwa karno-administracyjnego, „Nowe Prawo” 1966, no. 11.

Bafia J., Wzbogacenie środków zwalczania drobnej przestępczości, „Państwo i Prawo” 1968, no. 4-5. Chabros J., Żądanie i pobieranie za ustugi cen wyższych od obowiazujacych, „Zagadnienia Karno-Administracyjne" 1966, no. 5.

Dąbrowski W.F., Nowe aspekty orzecznictwa karno-administracyjnego, „Ruch Prawniczy, Ekonomiczny i Socjologiczny" 1967, no. 1.

Grzegorczyk T., Kodeks postępowania w sprawach o wykroczenia, Warszawa 2012.

Gubiński A., Areszt zasadniczy i zastępczy, „Zagadnienia Karno-Administracyjne” 1963, no. 6.

Gubiński A., Ewolucja stosowanych przez kolegia środków karnych i zasad wymiaru kary, „Zagadnienia Wykroczeń" 1977, no. 6.

Gubiński A., Siewierski M., Ustawa o przekazaniu niektórych drobnych przestępstw jako wykroczeń do orzecznictwa karno-administracyjnego. Komentarz, Warszawa 1967.

Hochberg L., Doniosłe zmiany w orzecznictwie karno-administracyjnym, „Służba MO” 1967, no. 1. Hochberg L., Rodzaje wykroczeń, „Zagadnienia Karno-Administracyjne” 1966, no. 5.

Jasiński J., Prawo bliżej odbiorcy, „Gazeta Sądowa i Penitencjarna” 1966, no. 20.

Jastrzębski L., Kradzież drewna z lasu, „Zagadnienia Karno-Administracyjne” 1966, no. 5.

Józwiak F., Zadania Milicji Obywatelskiej, „Zagadnienia Karno-Administracyjne” 1966, no. 5.

Kocel-Krekora Z., Kierunki rozwoju polskiego prawa wykroczeń, „Zagadnienia Wykroczeń” 1987, no. 3 .

Kolegia ds. wykroczeń w PRL (rozwiązania ustawowe i praktyka), Warszawa-Kraków 1987.

78 Article 178a of the Act of 6 June 1997 - Criminal Code (Journal of Laws 1997, no. 88, item 553).

${ }^{79}$ M. Łysko, Prace nad kodyfikacją materialnego prawa wykroczeń w Polsce Ludowej (19601971), Białystok 2016, pp. 322-323. 
Lewiński J., Wybrane zagadnienia z ustawy z dnia 17 czerwca 1966 r. o przekazaniu niektórych drobnych przestępstw jako wykroczeń do orzecznictwa karno-administracyjnego, „Nowe Prawo” 1967, no. 2.

Lityński A., Historia prawa Polski Ludowej, Warszawa 2006.

Łysko M., Prace nad kodyfikacją materialnego prawa wykroczeń w Polsce Ludowej (1960-1971), Białystok 2016.

Łysko M., Reforma prawa karno-administracyjnego Polski Ludowej z 1958 r., „Z Dziejów Prawa” 2014, vol. 7.

Łysko M., Socjalistyczna reforma orzecznictwa karno-administracyjnego Polski Ludowej, [in:] Księga pamiątkowa dla uczczenia pamięci Profesor Krystyny Kamińskiej, ed. A. Gaca, Torun 2013.

Mirończuk A., Oddziaływanie wychowawcze zakładów pracy, „Zagadnienia Karno-Administracyjne” 1966, no. 5.

Na antywykroczeniowym ,froncie”, „Zagadnienia Karno-Administracyjne” 1961, no. 5.

Nasze aktualne zadania, „Zagadnienia Karno-Administracyjne” 1961, no. 1.

Ogólne założenia ustawy, „Zagadnienia Karno-Administracyjne” 1966, no. 5.

Olszewski M., Stopień społecznego niebezpieczeństwa jako podstawa rozgraniczenia przestępstw i wykroczeń, „Państwo i Prawo” 1988, no. 4.

Orzecznictwo karno-administracyjne w latach 1963-1965, „Zagadnienia Karno-Administracyjne” 1966, no. 3-4.

Postan A., Duże zadania małej sprawiedliwości, „Gazeta Sądowa i Penitencjarna” 1966, no. 9.

Projekt kodeksu karnego. Część szczególna, Warszawa 1966.

Rot H., Problemy kodyfikacji prawa w PRL, Wrocław 1978.

Siarkiewicz K., Ksztaltowanie się ustroju kolegiów, „Zagadnienia Wykroczeń” 1977, no. 4-5.

Siewierski M., Przepisy procesowe, „Zagadnienia Karno-Administracyjne” 1966, no. 5.

Skupiński J., Kierunki doskonalenia polskiego prawa wykroczeń, „Studia Prawnicze” 1981, no. 4.

Skupiński J., Model polskiego prawa o wykroczeniach, Wrocław 1974.

Skupiński J., Przekazanie niektórych drobnych przestępstw do orzecznictwa karno-administracyjnego, „Państwo i Prawo” 1967, no. 1.

Szewczyk M., Problematyka nieletnich w ustawie o przekazaniu niektórych drobnych przestęstw jako wykroczeń do orzecznictwa karno-administracyjnego, „Palestra” 1968, no. 9.

Szewczyk M., Warunkowe zawieszenia wykonania kary aresztu orzeczonej przez kolegium za wykroczenie, „Państwo i Prawo” 1967, no. 5.

Szubert J., Odpowiedzialność karno-administracyjna w prawie o miarach i narzędziach pomiarowych, „Zagadnienia Karno-Administracyjne” 1966, no. 6.

Szumski J., Główne kierunki polityki karnej realizowane przez kolegia do spraw wykroczeń w latach 1972-1989, „Archiwum Kryminologii” 1993, vol. 19.

Śmietanka I., Z sądu do kolegium, „Gazeta Sądowa i Penitencjarna” 1970, no. 16.

Śmietanka I., Zasady odpowiedzialności i karania, ,Zagadnienia Karno-Administracyjne” 1966, no. 5. Walczak S., Niektóre problemy kodyfikacji prawa karnego, „Państwo i Prawo” 1968, no. 4-5.

Wytyczne Ministra Spraw Wewnętrznych w zakresie orzecznictwa karno-administracyjnego na rok 1960, „Poradnik dla Kolegiów Orzekających” 1960, no. 2.

\section{Legal acts}

Act of 15 December 1951 on Criminal-Administrative Jurisdiction (Journal of Laws 1951, no. 66, item 454).

Act of 13 July 1957 on Combating Profiteering and Protecting the Interests of Buyers and Agricultural Producers in Trade (Journal of Laws 1957, no. 39, item 171). 
Act of 2 December 1958 on Amending the Act of 15 December 1951 on Criminal-Administrative Jurisdiction (Journal of Laws 1958, no. 77, item 396).

Act of 18 June 1959 on Criminal Liability for Crimes Against Social Property (Journal of Laws 1959 , no. 36 , item 228).

Act of 17 June 1966 on the Transfer of Certain Minor Offences as Offences to Criminal-Administrative Jurisdiction (Journal of Laws 1966, no. 23, item 149).

Act of 19 April 1969 - Criminal Code (Journal of Laws 1969, no. 13, item 96).

Act of 20 May 1971 - Code of Conduct in Misdemeanour Cases (Journal of Laws 1971, no. 12, item 116).

Act of 20 May 1971 - Code of Misdemeanours (Journal of Laws 1971, no. 12, item 114).

Act of 20 May 1971 on the System of Colleges for Misdemeanours Cases (Journal of Laws 1971, no. 12 , item 118).

Act of 24 October 1986 on Amending Certain Provisions of the Law on Misdemeanours (Journal of Laws 1986, no. 39, item 193).

Act of 29 May 1989 on Amending Certain Provisions of Criminal Law, the Law on Misdemeanours and Other Acts (Journal of Laws 1989, no. 34, item 180).

Act of 8 June 1990 on Amending the Acts: Code of Criminal Procedure, Code of Conduct in Misdemeanour Cases, Law on the System of Colleges for Misdemeanours Cases and Labour Code (Journal of Laws 1990, no. 43, item 251).

Act of 6 June 1997 - Criminal Code (Journal of Laws 1997, no. 88, item 553).

Act of 6 June 1997 - Code of Criminal Procedure (Journal of Laws 1997, no. 89, item 555).

Act of 24 August 2001 - Code of Conduct in Misdemeanour Cases (Journal of Laws 2001, no. 106, item 1148).

Constitution of the People's Republic of Poland of 22 July 1952 (Journal of Laws 1952, no. 33, item 232).

Constitution of the Republic of Poland of 2 April 1997 (Journal of Laws 1997, no. 78, item 483 as amended).

Decree of 4 March 1953 on the Protection of Social Property Against Minor Attacks (Journal of Laws 1953, no. 17, item 69).

\section{STRESZCZENIE}

W okresie Polski Ludowej (1944-1989) rządzona przez komunistów Polska znajdowała się w strefie wpływów Związku Radzieckiego. Uchwalona w 1966 r. ustawa o przekazaniu niektórych drobnych występków jako wykroczeń do orzecznictwa karno-administracyjnego nadawała rangę wykroczeń licznej grupie dotychczasowych występków przeciwko mieniu i czynów godzących w interesy konsumentów. Przekazanie tych występków jako wykroczeń do właściwości kolegiów karno-administracyjnych miało na celu odciążenie sądów od rozpatrywania spraw o drobne czyny karalne. Operacji przekazania towarzyszyło wprowadzenie do prawa wykroczeń szeregu rozwiązań z dziedziny prawa karnego, co stworzyło warunki dla prowadzenia bardziej elastycznej polityki karnej w sprawach o wykroczenia. Ustawa o przekazaniu została w całości uwzględniona w uchwalonym w 1971 r. Kodeksie wykroczeń, którego część szczególna zawiera kolejną grupę wykroczeń powstałych z przekształcenia dotychczasowych występków. Ustawa o przekazaniu ostatecznie uplasowała prawo wykroczeń w obszarze szeroko pojmowanego prawa karnego, co skutkowało odejściem od stworzonej w okresie stalinowskim koncepcji prawa wykroczeń jako jednej z gałęzi prawa administracyjnego.

Słowa kluczowe: drobne czyny karalne; prawo wykroczeń; ustawa o przekazaniu; Polska Ludowa 